\title{
Teaching ethics during undergraduate teaching in Medical Schools in India
}

\author{
Shrivastava, S.R. ${ }^{1}$ \& Shrivastava, P.S. ${ }^{2}$
}

\begin{abstract}
An Indian Medical Graduate should ideally acquire five core competencies, nevertheless, for decades emphasis has been given only to the clinician role, while other attributes have been ignored. There is an immense and indispensable need to ensure that medical students should be exposed to principles of ethics and ethical practices during their undergraduate training at medical school. Keeping in mind that the duration of the course is already very long, the strategy to introduce ethics as an individual subject will not be regarded as a student-friendly step. In conclusion, ethics has a crucial role in the undergraduate teaching and training, and it is the need of the hour to take strategic steps to give adequate importance to ethics within the curriculum without increasing the duration of the course.
\end{abstract}

Keywords: Medical Education, Ethics, Educational outcomes

\section{Introduction}

The Medical Council of India has identified five core competencies, which an Indian Medical Graduate should possess, namely clinician, communicator, leader and member of the health care team, life-long learner and professional (Medical Council of India, 2011). For many years, throughout the entire undergraduate period, emphasis has been given only to the clinician role, while other roles have been neglected (Thirumoorthy, 2017; AlMahmoud et al., 2017).

${ }^{1}$ Vice Principal Curriculum, Member of the Medical Education Unit \& Institute Research Council, Associate Professor, Department of Community Medicine, Shri Sathya Sai Medical College \& Research Institute, Kancheepuram, Sri Balaji Vidyapeeth, India

${ }^{2}$ Associate Professor, Department of Community Medicine, Shri Sathya Sai Medical College \& Research Institute, Kancheepuram, Sri Balaji Vidyapeeth, India

Corresponding Author:

Dr. Saurabh RamBihariLal Shrivastava

3rd floor, Department of Community Medicine, Shri Sathya Sai Medical College \& Research Institute, Ammapettai village, Thiruporur - Guduvancherry Main Road, Sembakkam Post, Kancheepuram - 603108, Tamil Nadu, India

Email:drshrishri2008@gmail.com
There is no doubt that one of the primary goals of medical training is to produce a doctor with good knowledge of the subjects. Nevertheless, to become a successful doctor, that too amidst the rising demands of the clinical practice, the budding doctors have to be competent in all the ascertained five roles (Medical Council of India, 2011; Thirumoorthy, 2017; AlMahmoud et al., 2017).

\section{Necessity of Ethics in Undergraduate Teaching}

A key element of professional behavior is the ability and willingness of a doctor to work in agreement with the widely accepted moral norms and values (Ferreira-Padilla et al., 2016). This calls for an immense and indispensable need to ensure that medical students should be exposed to principles of ethics and ethical practices during their undergraduate training at medical school (Thirumoorthy, 2017; AlMahmoud et al., 2017). Acknowledging the need for medical and research ethics, in most of the undergraduate and graduate education and clinical training programs, teaching ethics to students has been regarded as an integral component (Medical Council of India, 2011; Thirumoorthy, 2017; Ferreira-Padilla et al., 2016; de la Garza et al., 2017). 


\section{Practical Challenges and Recommended Solutions}

Furthermore, it is very important to understand that the duration of the undergraduate period in Indian set-up is 4.5 years, and if ethics is introduced as a separate subject, the duration of the course might increase further, which will make the life of medical students even more stressful (Medical Council of India, 2011). Thus, instead of introducing it as a separate subject, the ethics component can be integrated throughout the duration of the course (Table 1) and in day-to-day clinical practice as well (by means of observation of the teachers during their clinical postings) (Medical Council of India, 2011).

Table 1: Year-specific objectives, teaching-learning methods, and assessment tools for teaching ethics

\begin{tabular}{llll}
\hline Year 1 & Year 2 & Year 3 & Year 4 \\
\hline
\end{tabular}

\begin{tabular}{lllll}
\hline & To develop empathy & To learn about & To obtain & To obtain informed \\
Objective & $\begin{array}{l}\text { and respect towards } \\
\text { peer, teachers, teaching } \\
\text { materials }\end{array}$ & $\begin{array}{l}\text { different types of } \\
\text { informed consent }\end{array}$ & $\begin{array}{l}\text { from standardized } \\
\text { patients }\end{array}$ & $\begin{array}{l}\text { consent from real } \\
\text { patients }\end{array}$
\end{tabular}

\begin{tabular}{lllll}
\hline & & & Handouts, & \\
$\begin{array}{l}\text { Teaching } \\
\text { and Learning } \\
\text { methods }\end{array}$ & $\begin{array}{l}\text { Small group teaching, } \\
\text { role plays, case } \\
\text { scenarios, etc. }\end{array}$ & $\begin{array}{l}\text { Lectures, handouts, } \\
\text { videos, etc. }\end{array}$ & $\begin{array}{l}\text { standardized } \\
\text { patients, problem- } \\
\text { based learning, } \\
\text { etc. }\end{array}$ & $\begin{array}{l}\text { Case-based } \\
\text { discussion, role } \\
\text { modeling, etc. }\end{array}$ \\
\hline
\end{tabular}

\begin{tabular}{|c|c|c|c|c|}
\hline $\begin{array}{l}\text { Assessment } \\
\text { tools }\end{array}$ & $\begin{array}{l}\text { Multiple Choice } \\
\text { Questions (MCQs), } \\
\text { Objective Structured } \\
\text { Practical Examination } \\
\text { (OSPE), etc. }\end{array}$ & $\begin{array}{l}\text { Multiple Choice } \\
\text { Questions (MCQs), } \\
\text { puzzles, } \\
\text { crosswords, short } \\
\text { notes, etc. }\end{array}$ & $\begin{array}{l}\text { Objective } \\
\text { Structured Clinical } \\
\text { Examination } \\
\text { (OSCE), etc. }\end{array}$ & $\begin{array}{l}\text { Work-place based } \\
\text { assessment (WPBA) } \\
\text { tools (Mini-Clinical } \\
\text { Examination, Direct } \\
\text { Observation of } \\
\text { Procedural Skills, } \\
\text { Multi-source } \\
\text { feedback, etc.) }\end{array}$ \\
\hline
\end{tabular}

However, educational outcomes have to be defined well in advance (Table 2). These outcomes essentially comprise of what behaviors should be promoted, what attitudes should be inculcated, what skills should be acquired, what knowledge should be learned, what students should experience over the period of training, which technology might support or enhance learning and how to ensure that learning can be sustained (Medical Council of India, 2011; Thirumoorthy, 2017; AlMahmoud et al., 2017; Ferreira-Padilla et al., 2016; de la Garza et al., 2017). In-fact, the above proposed educational outcomes can be identified for any clinical competency (Table 2) (Thirumoorthy, 2017; AlMahmoud et al., 2017; Ferreira-Padilla et al., 2016; de la Garza et al., 2017; Hally \& Walsh, 2016; Shrivastava et al., 2015). In addition, specific objectives, teachinglearning methods and appropriate assessment tools can be identified on a year-wise basis as depicted in Table 1 (AlMahmoud et al., 2017; Ferreira-Padilla et al., 2016; de la Garza et al., 2017; Hally \& Walsh, 2016; Shrivastava et al., 2015). 
Table 2: Able to understand the principles of ethics and apply them in clinical settings Educational Outcomes

\begin{tabular}{|c|c|c|}
\hline $\begin{array}{l}\text { Educational } \\
\text { Outcomes }\end{array}$ & $\begin{array}{c}\text { Early Outcomes } \\
\text { (Start of undergraduate period) }\end{array}$ & $\begin{array}{c}\text { Graduate Outcomes } \\
\text { (At the end of undergraduate period) }\end{array}$ \\
\hline Behavior & $\begin{array}{l}\text { Empathy towards peers and teaching } \\
\text { resources (like cadavers) }\end{array}$ & $\begin{array}{l}\text { Empathy towards patients in clinical } \\
\text { settings }\end{array}$ \\
\hline Attitude & $\begin{array}{l}\text { Being sensitive to ethical issues and cultural } \\
\text { values }\end{array}$ & $\begin{array}{l}\text { Demonstrates ethical practices and in } \\
\text { developing trust with the patients }\end{array}$ \\
\hline Skills & Obtaining informed consent, etc. & $\begin{array}{l}\text { Breaking bad news, communicates with } \\
\text { patients with compassion, etc. }\end{array}$ \\
\hline Knowledge & Being aware of the existing guidelines & $\begin{array}{l}\text { Abreast with recent updates on ethical } \\
\text { practices in patient care }\end{array}$ \\
\hline Experience & $\begin{array}{l}\text { With standardized patients either in } \\
\text { department or in community }\end{array}$ & $\begin{array}{l}\text { With real patients in hospital settings while } \\
\text { obtaining relevant history and clinical } \\
\text { examination }\end{array}$ \\
\hline Technology & $\begin{array}{l}\text { Audio-visual (videos of case-scenarios, } \\
\text { movies), lectures, etc. }\end{array}$ & $\begin{array}{l}\text { Videos, role plays, recording of their } \\
\text { interactions with patients and then showing } \\
\text { them the same, and giving appropriate } \\
\text { feedback, etc. }\end{array}$ \\
\hline Sustainability & $\begin{array}{l}\text { Sensitizing students about ethics at the time } \\
\text { of } \\
\text { - Foundation Course (when students enroll in } \\
\text { under-graduation in a medical college) } \\
\text { - White Coat Ceremony (after completion of } \\
\text { first year, in the third semester - when } \\
\text { students for the first time start dealing with } \\
\text { real patients during their clinical postings) }\end{array}$ & $\begin{array}{l}\text { It can be ensured by exposing students to } \\
\text { ethics } \\
\text { - Just before the start of their internship } \\
\text { - Day-to-day clinical practice by observing } \\
\text { their teachers (Role-modeling) }\end{array}$ \\
\hline
\end{tabular}

\section{Conclusion}

To conclude, as medical and research ethics remain an important aspect of the medical education and training, it is quite essential that specific objectives, educational outcomes, teaching-learning methods and assessment tools are defined for the same.

\section{References}

AlMahmoud, T., Hashim, M.J., Elzubeir, M.A. \& Branicki, F. (2017) Ethics teaching in a medical education environment: preferences for diversity of learning and assessment methods, Medical Education Online, 22, 1, p. 1328257

de la Garza, S., Phuoc, V., Throneberry, S., Blumenthal-Barby, J., McCullough, L. \& Coverdale, J. (2017) Teaching medical ethics in graduate and undergraduate medical education: A systematic review of effectiveness, Academic Psychiatry, 41, 4, pp. 520-525.
Ferreira-Padilla, G., Ferrández-Antón, T., LolasStepke, F., Almeida-Cabrera, R., Brunet, J. \& Bosch-Barrera, J. (2016) Ethics competences in the undergraduate medical education curriculum: the Spanish experience, Croatian Medical Journal, 57, 5, pp. 493-503.

Hally, E. \& Walsh, K. (2016) Research ethics and medical education, Medical Teacher, 38, 1, pp. 105-106

Medical Council of India, (2011) Vision - 2015. New Delhi: $\mathrm{MCl}$ press, pp. 1-26

Shrivastava, S.R., Shrivastava, P.S. \& Ramasamy, J. (2015) Informed consent in clinical research, CHRISMED Journal of Health and Research, 2, 2, pp. 183-185

Thirumoorthy, T. (2017) The ethics of medical education - The ethical and professional issues in teaching and learning medicine, ANNALS Academy of Medicine Singapore, 46, 9, pp. 331332 